\title{
Supplement and forage effects on fecal output estimates from an intra-ruminal marker device
}

\author{
KARLA J. HOLLINGSWORTH, DON C. ADAMS, TERRY J KLOPFENSTEIN, JAMES B. \\ LAMB, AND GUILLERMO VILLALOBOS
}

\begin{abstract}
Hollingsworth and Villalobos are graduate students and Klopfenstein is a professor, University of Nebraska-Lincoln; Adams is an associate professor and Lamb a research associate, University of Nebraska-Lincoln, West Central Research and Extension Center, Rt. 4, Box 46A, North Platte 69101.
\end{abstract}

Abstract

Three experiments were conducted to evaluate effects of supplemental protein and forage on marker estimated fecal output using an intraruminal continuous release marker device in grazing steers. In experiment 1, twelve steers were assigned to 3 treatments and fecal collections were made during a 6 -day period in December 1990 and again in February 1991. Treatments were: 1) range forage only, 2) range forage $+0.32 \mathrm{~kg}$ protein/day from a $70 \%$ soybean meal $-30 \%$ wheat pellet, and 3 ) range forage + $0.32 \mathrm{~kg}$ crude protein/day from $15.1 \%$ meadow hay. Fecal output estimates derived from the marker device were similar $(P>0.10)$ for all treatments and both periods. Fecal estimates derived from the marker device were greater $(P<0.01)$ than fecal output from total fecal collection $(3.5 \mathrm{~kg} /$ day vs $2.7 \mathrm{~kg} /$ day); the correlation between estimates from fecal collection and the marker device was 0.85 . In experiment 2 , ten steers were assigned to treatments 1 and 2 of experiment 1 during December 1991. Fecal output derived from the marker device was similar $(P>0.10)$ for the 2 supplement treatments. Fecal output estimates were greater $(P<0.10)$ for the marker device than fecal collection $(1.80 \mathrm{~kg} / \mathrm{day}$ vs $11.63 \mathrm{~kg} /$ day); the correlation between estimates from the marker device and total collection was 0.94. In experiment 3, fecal output was derived from the marker device during three 5day collection periods. Steers grazed upland range in July (green immature forage) and September (cured mature forage) and grazed subirrigated meadow (immature regrowth) in October. Fecal output estimates from the marker device were different $(P<0.05)$ between collection periods, (e.g., forage sources). When compared to total fecal collection, the marker device underestimated fecal output on range in July $(P<0.01,2.1 \mathrm{~kg} /$ day vs 2.5 $\mathrm{kg} /$ day) and on meadow in October $(P<0.01,2.6 \mathrm{~kg} /$ day vs 3.5 $\mathrm{kg} /$ day). Correlations between the marker device and fecal collection were 0.93 in July and 0.99 in October, respectively. Estimates from the marker device and total fecal collection were similar $(P>0.10 ; r=0.93)$ on range in September. Protein supplements had no effect on fecal estimates derived from chromic oxide released from a marker device, but the marker estimates were affected by forage source. Correlation between fecal collection and the marker method is high; however, total fecal collection should be used to correct fecal output derived by the marker device for each forage source.

Mention of a unde name or product does not constitute a recommendation or endorsement for use by the University of Nebraska-Lincoln. Published with the approval of the director of the Nebraska Agr. Res. Div. and Joumal Ser. No. 10410.

Accepted 13 Aug 94.
Key Words: beef cattle, rangeland, pasture, intake, chromic oxide

Estimates of fecal output and forage indigestibility have traditionally been used to predict intake in grazing ruminants. Therefore, an accurate estimate of fecal output is important. Chromic oxide has been a popular marker to estimate fecal output (Raleigh et al. 1980). Chromium has been mordanted to fiber (Uden et al. 1980), impregnated in paper (Kiesling et al. 1969), mixed in supplement (Hopper et al. 1978), and contained in a gelatin capsule (Prigge et al. 1981). The most recent and promising form of administration is the intra-ruminal controlled marker release device (Adams et al. 1991). The marker device has considerable potential for grazing animal research. It reduces labor associated with daily dosing and total fecal collection, allowing more animals to be used, which should increase accuracy and reduce variation.

The marker release rate associated with the device appears to be somewhat variable (Adams et al. 1991) and research with sheep indicates it may be affected by diet (Parker et al. 1989) or supplementation in confined sheep (Hatfield et al. 1991). Our objective was to determine if marker estimated fecal output, using the marker release device in cattle, was affected by forage type or protein supplementation in a grazing situation.

\section{Methods and Materials}

Three experiments were conducted on range or subirrigated meadow. The range is generally a choppy sandhill site. Dominant grass species were blue grama [Bouteloua gracilis (H.B.K.) Lag. ex Giffiths], little bluestem [Schizachyrium scoparium (Michx.) Nash], prairie sandreed [Calamovilfa longifolia (Hook). Scribn.], sand bluestem (Andropogon hallii Hack.), switchgrass (Panicum virgatum L.), sandlovegrass [Eragrostis trichodes (Nutt.) Wood], and indiangrass [Sorghastrum nutans (L.) Nash]. Common forbs and shrubs included western ragweed (Ambrosia psilostrachya Dc.) and leadplant [Amorpha canescens (Nutt.) Pursh]. Subirrigated meadow soils were classified as Gannett-Loup fine sandy loam (coarse-loamy, mixed mesic Typic Haplaquoll). Dominant meadow vegetation was smooth bromegrass (Bromus inermis Leyss.) redtop (Agrostis stolonifera L.), timothy (Phleum pratense L.), slender wheatgrass [Agropyron trachycaulum (Link) Malte], quackgrass [A. repens (L.) Beauv.], Kentucky bluegrass (Poa pratensis L.), prairie cordgrass (Spartina pectina- 
ta Link), and several species of sedges (Carex spp.), and rushes (Juncus spp. and Eleocharis spp.). Less abundant grass species were big bluestem (Andropogon gerardii Vitman), indiangrass [Sorghastrum nutans (L.) Nash], and switchgrass (Panicum virgatum L.). Legumes were a minor component of the vegetation.

In experiment 1 , twelve steers ( 4 steers/treatment, average body $w t=273 \mathrm{~kg}$ ) grazing winter range were randomly allotted to 3 treatments: 1) no supplement, 2) $1.2 \mathrm{~kg} \cdot \mathrm{steer}^{1} \bullet \mathrm{day}^{-1}$ of a $70 \%$ soybean meal:30\% wheat pellet (37\% crude protein), or 3) 2.2 $\mathrm{kg} \cdot$ steer $^{-1}$ day $^{-1}$ of meadow hay supplement (15.1\% crude protein). All steers were orally dosed with an intraruminal continuous marker release device' 5 days before 6-day fecal collection period. Total fecal collections were made using fecal collection bags and a once daily rectal grab sample of feces $(300-500 \mathrm{~g})$ was collected. Once daily sampling with the release device was considered sufficient based on fecal excretion pattern of chromium and of chromic oxide release rate from the marker release device reported in other studies (Ellis et al. 1981, 1982; Furnival et al. 1990a, 1990b; Brandyberry et al. 1991). The first collection period was 10 December through 15 December 1990, while the second collection was 5 February through 13 February 1991. Both collections were made in the same pasture of native Sandhills range at the Gudmundsen Sandhills Laboratory near Whitman, Nebr. At 0700 each morning, rectal grab samples were taken for chromium analysis and fecal bags were emptied, mixed, and subsampled for organic matter analysis. Fecal output from total collection and the marker device were compared with a split-splitsplit plot design. Supplement treatments were the main plot, collection periods were the subplot, day was the sub-sub plot, and fecal output from total collection and the marker device were the sub-sub-sub plot. Main plot was tested by steer(treatment), subplot by steer(treatment $x$ period), sub-sub plot by steer $x$ period $x$ day (treatment), sub-sub-sub plot by the residual.

In experiment 2 , ten steers (average body wt $=230 \mathrm{~kg}$ ) grazing winter range (same site as in experiment 1 ) were randomly allotted to 2 treatments ( 5 steers/treatment): 1) no supplement and 2) 1.2 - $^{-1 e e r^{-1}}$ day $^{1}$ of a $70 \%$ soybean meal:30\% wheat pellet (37\% crude protein). All steers were orally dosed with a marker release device 5 days before a 5-day fecal collection period. Rectal grab samples were taken for chromium analysis and total fecal collections were made as in experiment 1. Fecal collection began 11 December and ended 16 December 1991. Fecal output from fecal collection and from the marker device were compared with a split-split plot design. Supplement treatments were the main plot, day was the subplot, and fecal output from total collection and the marker device were the sub-sub plot. Main plot was tested by steer(treatment) and subplot by steer $\times$ day(treatment), and the sub-sub plot by the residual.

In experiment 3, eight nonsupplemented steers (average body $w t=400 \mathrm{~kg}$ ) grazing Sandhills range or subirrigated meadow were orally dosed with a marker release device as in experiment 1 for three 5-day fecal collection periods. The 3 collection periods provided diets with different plants or maturity and different chemical composition (Table 1). Rectal grab samples were taken for chromium analysis and total fecal collections were made as in experiment 1 except that fecal bags were also emptied, mixed, and subsampled in the evenings, as well as mornings. The first collection was 9 July through 13 July 1991 on native summer

'Captec Chrome manufactured by Captec Pty. Ltd., Australia, distributed internationally by Nufarm limited, Manu Street Otahunu, P.O. Box 22-407, Auckland 6. New Zealand.
Table 1. Neutral detergent fiber (NDF), acid detergent fiber (ADF), and crude protein (CP) content of meadow and range diets from 3 experiments.

\begin{tabular}{llccc}
\hline \hline & Forage & CP & NDF & ADF \\
& & $-\ldots$ of organic matter $\ldots .$. \\
\hline Experiment 1 & & & & \\
December 1990 & Range & 4.6 & 68.5 & 45.6 \\
February 1991 & Range & 6.8 & 64.9 & 49.5 \\
Experiment 2 & & & & \\
December 1991 & Range & 4.5 & 71.5 & 46.3 \\
Experiment 3 & & & & \\
July 1991 & Range & 8.2 & 67.4 & 39.5 \\
September 1991 & Range & 7.3 & 64.2 & 43.8 \\
October 1991 & Meadow & 11.2 & 51.7 & 42.5 \\
\hline
\end{tabular}

Sandhills range. The second collection was 17 September through 21 September 1991 in the same pasture as the first collection when the forage was more mature. The third collection was 21 October through 26 October 1991 on subirrigated meadow. Fecal output from fecal collection bags and from the marker device were compared in a split-split plot design. Collection periods (i.e. source of forage) were the main plot, day was the subplot, and fecal output from total collection and the marker device were the sub-sub plot. Main plot was tested with steer(period), the sub plot by steer $x$ day (period), and the sub-sub plot by the residual. Simple correlations between fecal output from total fecal collection and the marker device were determined in each experiment.

One day during each fecal collection period of experiments 1 , 2 , and 3 forage diets were collected during a 30-45 minute grazing period from 8 esophageally-fistulated cows. Fecal samples were dried at $60^{\circ} \mathrm{C}$ and fistula-forage samples were freeze dried and ground in a Wiley Mill to pass a 1-mm screen. Fecal grab samples were prepared for chromium analysis as described by Williams et al. (1962) and chromium concentration as determined by atomic absorption spectroscopy. Dry matter and ash of fecal and fistula forage samples were determined by standard procedures (AOAC 1984). Extrusa samples were also analyzed for crude protein (AOAC 1984) and neutral detergent fiber (Goering and Van Soest 1970). Fecal output was determined by dividing the daily release of chromium of the marker release device (provided by the manufacturer) by the concentration of chromium in the feces.

\section{Results and Discussion}

In experiment 1 , the supplement treatment $x$ period and day $\times$ supplement treatment interactions were nonsignificant $(P>0.10)$. Daily fecal output estimates from total fecal collection and the marker device varied $(P<0.10)$, but were consistently higher for the marker device than total fecal collection (Fig. 1). The correlation between the marker device and fecal collection methods was 0.85 . Fecal output estimates averaged across 6-day collection periods from the marker device were similar $(P>0.10)$ for supplement treatments and periods of December and February. The fecal output estimated by the marker device ( $3.49 \mathrm{~kg} / \mathrm{day})$ was higher $(P<0.01)$ than that from total fecal collection $(2.70$ $\mathrm{kg} /$ day).

In experiment 2 , day effects were significant $(P<0.10)$, and the 


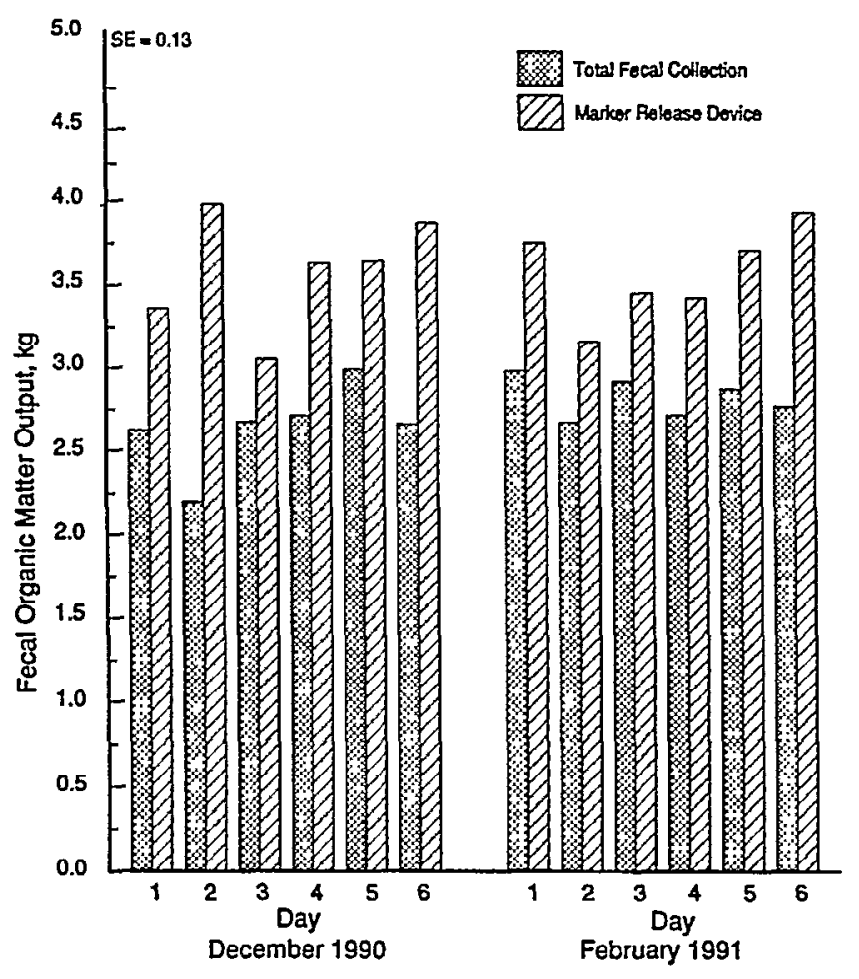

Fig. 1. Daily organic matter fecal output and standard error (SE) estimated by total fecal collection and a continual marker release device from steers on 3 supplement treatments grazing Sandhills winter range during 2 collection periods in December and February (Experiment 1). Day effects were significant $(P<0.10)$. Fecal output from marker release device was greater $(P<0.01)$ than total fecal collection. Supplement, period, and supplement $\div$ period interaction were not significant $(P>0.10)$.

day $\times$ supplement treatment interaction was non-significant $(P>0.10)$. Fecal output estimates derived from the marker device (average of 5 days) were similar $(P>0.10)$ for supplemented and non-supplemented steers. Fecal output estimated by the marker device $(1.80 \mathrm{~kg} / \mathrm{day})$ was greater $(P<0.10)$ than but highly correlated $(r=0.94)$ with that from total fecal collection $(1.63 \mathrm{~kg} /$ day; Fig. 2).

In sheep trials, with a smaller but similar marker release device, Hatfield et al. (1991) found that supplemental barley affected fecal output estimates from the marker device in confinement, but not under grazing. For winter grazing trials, a necd for multiple day sampling and adjustment of fecal output by total fecal collection are needed, but protein supplement effects on fecal output estimates appear to be insignificant.

In experiment 3 , fecal collections were to be emptied once each 24 hours. However, after 24 hours on day one of fecal collections on range forage in July, fecal output was greater than collection bags would hold. Therefore, fecal bags were emptied at 12-hour intervals during experiment 3 . Day one of July range data was not used in analysis.

In experiment 3 , the day of collection $\times$ forage source interaction was significant $(P<0.01)$. Fecal output by the marker device was lower $(P<0.01)$ on native range in July $(\mathrm{r}=0.93)$ and on meadow in October ( $r=0.99$; Figs. 3 and 4 ) than total fecal collection. Total fecal output estimates from the marker device were similar $(P>0.10)$ to estimates from total fecal collection on native

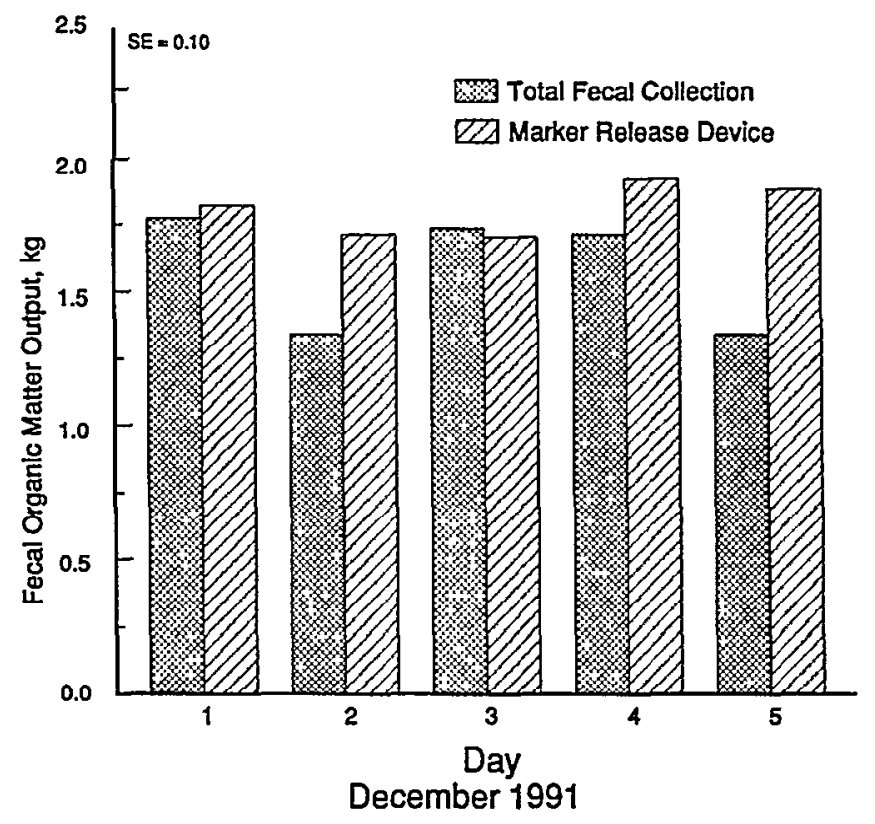

Fig. 2. Daily organic matter fecal output and standard error (SE) estimated by total fecal collection and a continuous marker release device from steers on 2 supplement treatments grazing Sandhills winter range during December (Experiment 2). Day effects were significant $(P<0.10)$. Fecal output from total fecal collection and marker release device differed $(P<0.10)$.

range in September $(r=0.87)$. As in experiment 1 , fecal output varied by day $(P<0.01)$. During July and October experiments,

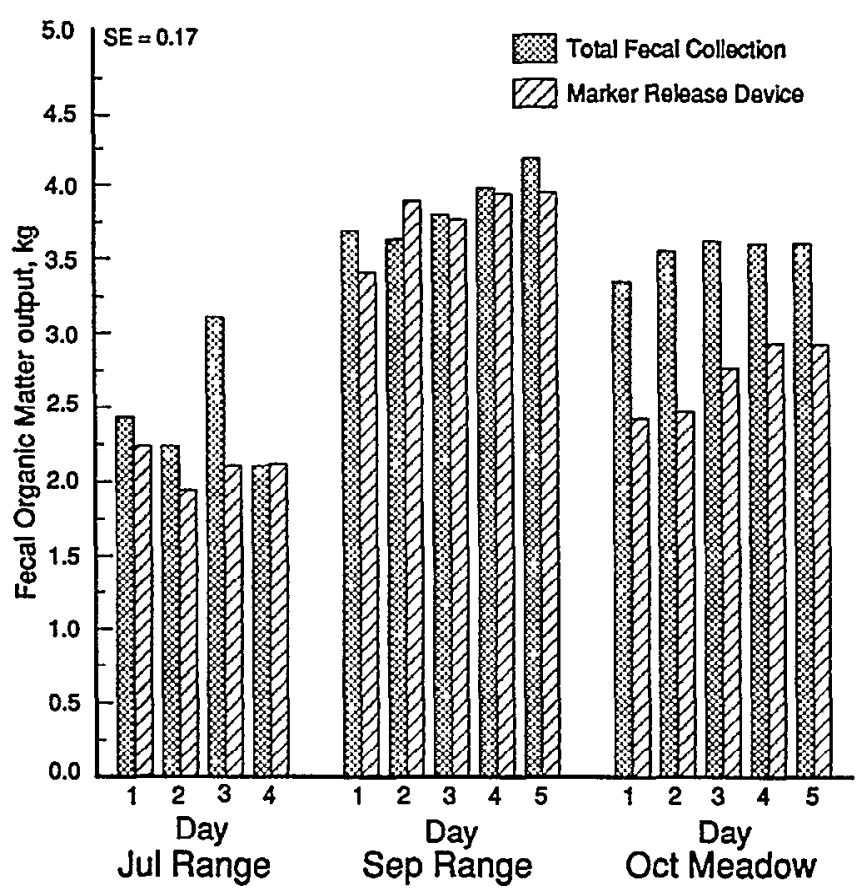

Fig. 3. Daily organic matter fecal output and standard error (SE) estimated by total fecal collection and a continuous release marker device from steers grazing Sandhills range or subirrigated meadow during 4- 5-day collection periods (Experiment 3). Day $\times$ periods effect were significant $(P<0.01)$. 


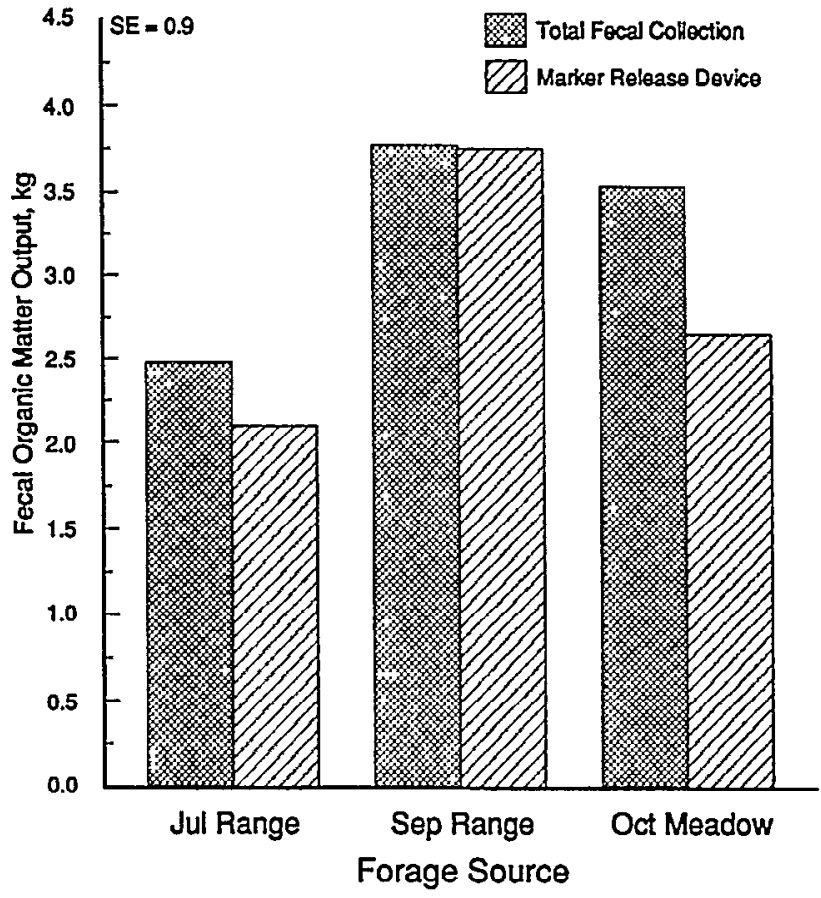

Fig. 4. The effects of forage source on fecal output and standard error (SE) estimates from a continuous marker release device and total fecal collection averaged across 4- or 5-day collection periods (Experiment 3). Fecal output from a total fecal collection was greater $(P<0.01)$ than fecal output from marker device for Jul. range and Oct. meadow. Fecal output for Sept. range was similar $(P>0.10)$ for total fecal collection and marker device.

daily fecal output was consistently lower for the maker device than for fecal collection (Fig. 3).

Our results are consistent with other studies. Using a smaller marker device in sheep fed 3 different forage diets in confinement, Parker et al. (1989) found small but significant differences in release of $\mathrm{Cr}$ between the 3 diets. Adams et al. (1991) observed differences between fecal output estimated by the marker device and total fecal collection for steers on native range, but found no differences between marker device estimates and total fecal collection in steers grazing fall wheatgrass pasture. In a confinement study with cattle, Pinchak and Hutcheson (1992) found that fecal estimates were similar for prairie hay and alfalfa hay. The results of experiment 3 indicate that changing forage source during the growing season necessitates comparing fecal output from the marker device to total fecal collection on a subset of animals for each grazing period or source of forage. Fecal output estimates by the marker device for experiments 1,2 , and 3 were corrected by multiplying fecal output from the marker device by a correction factor; the correction factor was fecal output from the marker device $\div$ fecal output from total fecal collection. When the corrected fecal output estimates from the marker device were compared to total fecal collection by the statistical models described for each experiment in the materials and methods, no differences were detected $(P>0.10)$ between the marker device and total fecal collection.

\section{Conclusions}

For grazing cattle, we concluded that estimates of fecal output from the marker device were not influenced by supplementing winter range with protein. Estimates of fecaloutput by the marker device were affected by forage source (i.e., plant maturity, composition, etc.). We recommend that for each manufacturer's production batch of marker release devices and for each set of forage conditions the fecal output estimates from the marker device be corrected by total fecal collection and that multiple day collection be utilized. This conclusion is in agreement with recommendations by other researchers (Pinchak and Hutcheson 1992, Adams et al. 1991). If corrections are made for variation in manufacturers' batches and for forage conditions, the marker device for cattle appears to be a reliable method for obtaining estimates of fecal output in grazing trails.

\section{Literature Cited}

Adams, D.C., R.E. Short, M.M. Borman, and M.D. MacNeil. 1991. Estimation of fecal output with an intra-ruminal continuous release marker device. J. Range Manage. 44:204-207.

AOAC. 1984. Offical Methods of Analysis (14th ed.). Association Offical Analytical Chemists, Washington D.C.

Brandyberry, S.D., R.C. Cochran, E.S. Vanzant, and D.L. Harmon. 1991. Technical note: Effectiveness of different methods of continuous marker administration for estimating fecal output. J. Anim. Sci. 69:4611-4616.

Ellis, K.J., R.H. Laby, and R.G. Burns. 1981. Continuous controlledrelease administration of chromic oxide to sheep. Proc. Nutr. Soc. Aust. 6:145.

Ellis, K.J., R.H. Laby, P. Costigan, K. Zirkler, and P.G. Choice. 1982. Continuous administration of chromic oxide to grazing cattle. Proc. Nutr. Soc. Aust. 7:177.

Furnival, E.P., J.L. Corbett, and M.W. Inskip. 1990a. Evaluation of controlled release devices for administration of chromium sesquioxide using fistulated grazing sheep. I. Variation in marker concentration in faeces. Aust. J. Agr. Res. 41:969-975.

Furnival, E.P., J.L. Corbett, and F.S. Pickering. 1990b. Evaluation of controlled release devices for administration of chromium sesquioxide using fistulated grazing sheep. II. Variation in rate of release from the device. Aust. J. Agr. Res. 41:977-986.

Goering, H.K., and P.J. Van Soest. 1970. Forage fiber analyses (apparatus reagents, procedures and some applications). Agr. Handb. 379. ARS, USDA, Washington, D.C.

Hatfield, P.G., J.W. Walker, H.A. Glimp, and D.C. Adams. 1991. Effect of level of intake and supplemental barley on marker estimates of fecal output using an intraruminal continuous-release chromic oxide bolus. J. Anim. Sci. 69:1788-1794.

Hopper, J.T., J.W. Holloway, and W.T. Butts, Jr. 1978. Animal variation in chromium sesquioxide excretion patterns of grazing cows. J. Anim. Sci. 46:1096-1102.

Kiesling, H.E., H.A. Barry, A.B. Nelson, and C.H. Herbel. 1969. Recovery of chromic oxide administration in paper to grazing steers. J. Anim. Sci. 29:361-364.

Parker, WJ., S.N. McCutcheon, and D.H., Carr. 1989. Effect of herbage type and level of intake on the release of chromic oxide from intraruminal controlled release capsules in sheep. New Zealand J. Agr. Res. 32:537-546.

Pinchak, W.E., and D.P. Hutcheson. 1992. Effects of restricted forage intake in confinement on estimated fecal output from a sustained release bolus. J. Range Manage. 45:129-132.

Prigge, E.C., G.A. Varga, J.L. Vincini, and R.L. Reid. 1981. Comparison of ytterbium chloride and chromium sesquioxide as fecal indicators. $J$. Anim. Sci. 53:1629-1633.

Raleigh, R.J., R.J. Kartchner, and L.R. Rittenhouse. 1980. Chromic oxide in range nutrition sutdies. Oregon State Univ. Corvallis Bull. 641.

Uden, P., P.E. Colucci, and P.J. Van Soest. 1980. Investigations of chromium, cerium, and cobalt as markers in digesta rate of passage studies. J. Sci. Food Agr. 31:625-632.

Williams, C.H., D.J. David, and O. Iismaa. 1962. The determination of chromic oxide in faeces samples by atomic absorption spectrophotometry. J. Agr. Sci. (Camb.) 59:381-385. 